\title{
Autoimmunity and cystatin SA 1 deficiency behind chronic mucocutaneous candidiasis in autoimmune polyendocrine syndrome
}

\author{
Emma Lindh ${ }^{1 *}$, Johan Brännström ${ }^{1}$, Petra Jones ${ }^{1}$, Fredrik Wermeling ${ }^{1}$, Signe Hässler ${ }^{1}$, Corrado Betterle ${ }^{2}$, \\ Ben Zion Garty ${ }^{3}$, Mats Stridsberg ${ }^{4}$, Björn Herrmann ${ }^{5}$, Mikael Cl Karlsson', Ola Winqvist ${ }^{1}$
}

From 7th European Workshop on Immune-Mediated Inflammatory Diseases

Noordwijk aan Zee, the Netherlands. 28-30 November 2012

Patients with the monogenic disease autoimmune polyendocrine syndrome type I (APS I) develop autoimmunity against multiple endocrine organs and suffer from chronic mucocutaneous candidiasis (CMC), a paradoxical complication with an unknown mechanism. We report that saliva from APS I patients with CMC was defective in inhibiting growth of $C$. albicans in vitro and had reduced levels of a salivary protein identified as cystatin SA1. In contrast, APS I patients with no CMC expressed salivary cystatin SA1 and could inhibit $C$. albicans to the same extent as healthy controls. We evaluated the anti-fungal activity of cystatin SA1 and found that synthesized full length cystatin SA1 efficiently inhibited growth of C. albicans in vitro. Moreover, APS I patients exhibited salivary IgA autoantibodies recognizing myosin-9, a protein expressed in the salivary glands that also produce cystatin SA1, thus linking autoimmunity to cystatin SA1 deficiency and CMC. This data suggests an autoimmune mechanism behind CMC in APS I and provide rationale for evaluating cystatin SA1 in antifungal therapy.

\begin{abstract}
Author details
${ }^{1}$ Translational Immunology Unit, Dept. of Medicine, Karolinska Institutet, Stockholm, Sweden. ${ }^{2}$ Endocrinology Unit, Dept. of Medical and Surgical Sciences, University of Padua, Padua, Italy. ${ }^{3}$ Dept. of Pediatrics, Schneider Children's Medical Center of Israel, Tel Aviv University, Israel. ${ }^{4}$ Section of Clinical Chemistry, Dept. of Medical Sciences, Uppsala University Hospital, Uppsala, Sweden. ${ }^{5}$ Section of Clinical Bacteriology, Dept. of Medical Sciences, Uppsala University Hospital, Uppsala, Sweden.
\end{abstract}

Published: 28 November 2012

'Translational Immunology Unit, Dept. of Medicine, Karolinska Institutet, Stockholm, Sweden

Full list of author information is available at the end of the article
doi:10.1186/1479-5876-10-S3-P58

Cite this article as: Lindh et al: Autoimmunity and cystatin SA 1 deficiency behind chronic mucocutaneous candidiasis in autoimmune polyendocrine syndrome. Journal of Translational Medicine 2012 10(Suppl 3):P58.
Submit your next manuscript to BioMed Central and take full advantage of:

- Convenient online submission

- Thorough peer review

- No space constraints or color figure charges

- Immediate publication on acceptance

- Inclusion in PubMed, CAS, Scopus and Google Scholar

- Research which is freely available for redistribution
() Biomed Central
C Biomed Central

(c) 2012 Lindh et al; licensee BioMed Central Ltd. This is an Open Access article distributed under the terms of the Creative Commons Attribution License (http://creativecommons.org/licenses/by/2.0), which permits unrestricted use, distribution, and reproduction in any medium, provided the original work is properly cited. 